\title{
Cotesia flavipes Cameron (Hymenoptera: Braconidae) alters the nutrients in the hemolymph, fat body, and cytochemistry of Diatraea flavipennella Box (Lepidoptera: Crambidae) hemocytes
}

\author{
Cotesia flavipes Cameron (Hymenoptera: Braconidae) altera \\ nutrientes na hemolinfa, corpo gorduroso e citoquímica de \\ hemócitos em Diatraea flavipennella Box (Lepidoptera: Crambidae)
}

\author{
Eliana Maria dos Passos $^{1 *}$; Valéria Wanderley-Teixeira ${ }^{2}$; Ana Lucia Figueiredo \\ Porto $^{2}$; Edmilson Jacinto Marques ${ }^{3}$; Álvaro Aguiar Coelho Teixeira²; Flávio \\ Oliveira Silva ${ }^{4}$
}

\begin{abstract}
Nutritional and physiological interactions depend on the evolutionary history of the host-parasitoid interaction considering that the host's regulation by the parasitoid is species-specific. Cotesia flavipes Cameron was introduced in Brazil in the 70's to be used in the control of Diatraea sugarcane borer complex; however, Diatraea flavipennella Box is restricted to Brazil. Thus, this study investigated the possible nutritional changes in the hemolymph and fat body, and cytochemistry of $D$. Alavipennella hemocytes parasitized by Cotesia flavipes. The levels of nutrients were quantified using colorimetric tests in the hemolymph and fat body. Levels of acidic polysaccharides, mucin, and lipids were investigated only in hemocytes using cytochemical techniques. In addition, histological sections of parasitized and non-parasitized caterpillars were prepared to observe volume changes and the presence of glycogen in the fat body. The results showed a reduction in protein and lipid concentration in the hemolymph of parasitized caterpillars. The parasitism reduced the levels of total carbohydrate, glycogen, and protein in the fat body and almost completely consumed the perivisceral fat body. It changed the cytochemistry of hemocytes and reduced acidic glycans in prohemocytes and oenocytoids, mucin in plasmatocytes and granulocytes, and lipids in adipohemocytes, granulocytes, and prohemocytes. We concluded that the presence of the parasitoid leads to different changes in D. flavipennella hemolymph and fat body and alters the cytochemistry of hemocytes causing a significant reduction in the reserve tissue. The results from this study contribute to consolidating the use of $C$. flavipes in biological control programs targeting D. flavipennella in sugarcane crops.
\end{abstract}

Key words: Sugarcane borer. Fat body. Hemocyte. Hemolymph. Parasitoid.

\section{Resumo}

A interação nutricional e fisiológica depende da história evolutiva da interação entre hospedeiro e parasitoide, sendo a regulação do hospedeiro pelo parasitoide espécie-específica. Cotesia flavipes

\footnotetext{
Pesquisador, Empresa de Desenvolvimento Agropecuário de Sergipe, EMDAGRO, Aracaju, SE, Brasil. E-mail: bisologa@ hotmail.com

2 Profs., Departamento de Morfologia e Fisiologia Animal, Universidade Federal Rural de Pernambuco, UFRPE, Recife, PE, Brasil. E-mail: valeria.wanderley@ufrpe.br; analuporto@yahoo.com.br; alvaro.teixeira@ufrpe.br

3 Prof., Departamento de Agronomia, UFRPE, Recife, PE, Brasil. E-mail: edmilson.marques@ufrpe.br

4 Discente, Departamento de Morfologia e Fisiologia Animal, UFRPE, Recife, PE, Brasil. E-mail: foliveirasilva@gmail.com

* Author for correspondence
} 
Cameron foi introduzida no Brasil na década de 70 para o controle do complexo de brocas Diatraea, contudo Diatraea flavipennella Box é restrita ao Brasil. Assim, este estudo investigou as possíveis alterações nutricionais da hemolinfa e do corpo gorduroso, e citoquímica dos hemócitos de $D$. flavipennella parasitada por C. Alavipes. Os níveis de nutrientes foram quantificados por meio de testes colorimétricos da hemolinfa e corpo gorduroso. Já os níveis de glicanos ácidos, mucina e lipídeo foram investigados, somente nos hemócitos, utilizando técnicas citoquímicas. Adicionalmente, cortes histológicos da lagarta parasitada e não parasitada foram preparados para observar alterações no volume e na presença de glicogênio no corpo gorduroso. Os resultados mostraram uma redução na concentração de proteína e lipídeos na hemolinfa de lagartas parasitadas. O parasitismo reduziu os níveis de carboidratos totais, glicogênio e proteína no corpo gorduroso e consumiu quase todo o corpo gorduroso perivisceral. Parasitismo alterou a citoquímica dos hemócitos, reduzindo glicanos ácidos em prohemócitos e oenocitóides, mucina em plasmatócitos e granulócitos, e lipídeos em adipohemócitos, granulócitos e prohemócitos. Concluímos que o parasitoide leva a diferentes mudanças na hemolinfa e corpo gorduroso de $D$. flavipennella, altera a citoquímica de hemócitos e causa redução significativa no tecido de reserva. Os resultados deste estudo contribuem para consolidar o uso de $C$. flavipes em programas de controle biológico de $D$. flavipennella na cultura da cana-de-açúcar.

Palavras-chave: Broca da cana-de-açúcar. Corpo gorduroso. Hemócito. Hemolinfa. Parasitoide.

\section{Introduction}

Parasitoids that develop their larval stage within the host depend on the host's nutrients. Therefore, they manipulate the host's physiology to increase the availability of nutrients and meet their nutritional requirements (KAESLIN et al., 2005; SALVADOR; CÔNSOLI, 2008; JERVIS et al., 2008). This manipulation involves alterations on the host's endocrine systems altering the synthesis, release, metabolism, and action of hormone groups responsible for growth, development, and reproduction regulation (EDWARDS et al., 2001; BECKAGE; GELMAN, 2004). Endoparasitic wasps use various methods to manipulate the physiology of their hosts such as polydnaviruses, venom, and teratocytes, which determine each mode of action (LANZREIN et al., 2001; BECKAGE; GELMAN, 2004; ESPAGNE et al., 2004; KROEMER; WEBB, 2004).

Parasitoid larvae use nutrients available in the host's hemolymph (NAKAMATSU; TANAKA, 2004). However, the fat body is responsible for the metabolism of lipids, carbohydrates, protein synthesis, and amino acids (ARRESE; SOULAGES, 2010; VISSER et al., 2010); its contact with the hemolymph is vital for the proper adjustment of changes in the concentration of precursors of circulating energy (GULLAN; CRANSTON, 2007; ARRESE; SOULAGES, 2010). Metabolic changes in the fat body of parasitized insects are commonly attributed to parasitization (BECKAGE; GELMAN, 2004).

The endoparasitoid Cotesia flavipes Cameron (Hymenoptera: Braconidae) was introduced in Brazil in 1974 to control the Diatraea complex borer, which causes damage to sugar cane cultures (MENDONÇA et al., 1977; FREITAS et al., 2006). Its development period within the host varies from 8 to 10 days (CAMPOS-FARINHA et al., 2000; PINHEIRO et al., 2010). The borer complex comprises two predominant species, Diatraea saccharalis Fabricius (Lepidoptera: Crambidae) and Diatraea flavipennella Box (Lepidoptera: Crambidae), the latter with an occurrence restricted to the northeastern region of Brazil (MENDONÇA, 1996; FREITAS et al., 2006).

Previous studies showed that parasitoids affect their host's physiology by inducing metabolic changes in tissues and hemolymph and altering protein, carbohydrates, and lipids levels (BAE; KIM, 2004; LEE et al., 2005; SALVADOR; CÔNSOLI, 2008). However, the involvement 
of hemocyte components in the parasite-host interaction has not been reported. Pech and Strand (1996) reported that the immune functions of hemocytes in specific species might be performed by cells other than hemocytes. These authors claimed that the study of the function of hemocytes could be used to characterize cell types through the correlation between ultrastructural morphology and biochemical changes in cytoplasmic components.

However, it is known that nutritional and physiological interaction depends on the evolutionary history of that interaction because the parasitoid's host regulation is species-specific (WHITFIELD, 1998; NAKAMATSU et al., 2002). To date, studies on host-parasitoid interactions between C. flavipes and D. flavipennella are rare (PASSOS et al., 2014); since introduced in Brazil, this parasitoid has been produced in the laboratory on D. saccharalis and released in the field to control both borer species. A reversal predominance of the sugarcane borer species occurred in the last 30 years in the state of Alagoas in Brazil (FREITAS et al., 2006) showing D. Alavipennella as currently the predominant species in Northeastern Brazil. This fact brought the possibility of development of $C$. flavipes in this host and its efficiency to control this pest into question.

This study investigated the $C$. flavipes- $D$. flavipennella interaction to evaluate nutrient levels in the hemolymph and fat body, and the cytochemistry of $D$. Alavipennella hemocytes after parasitism. The study aimed to demonstrate that this parasitoid can manipulate the host's physiology to meet its nutritional needs for development and thus contribute to consolidate biological control programs targeting this pest in sugarcane crops.

\section{Materials and Methods}

\section{Collection of Insects}

Caterpillars of D. Alavipennella were obtained from a population reared in the Insect Pathology
Laboratory, Department of Agronomy, Federal Rural University of Pernambuco $\left(27 \pm 1{ }^{\circ} \mathrm{C}, 70 \%\right.$ $\mathrm{RH}$, and 12:12 $\mathrm{h}$ photoperiod); this population was fed an artificial diet (ARAÚJO et al., 1985), which was modified from Hensley and Hammond Júnior (1968). Parasitoids were provided by the ASPLANPB (Sugarcane Cropper's Association of Paraíba - Brazil) in the pupal stage. D. flavipennella (sixth instar) caterpillars were manually offered to adult parasitoid females (24 h of age) in each bioassay; parasitism was verified through the observation of the parasitoid's ovipositor introduction in caterpillars. The control group was composed of non-parasitized caterpillars. Parasitized and nonparasitized caterpillars were individually placed in plastic pots, fed an artificial diet and maintained in the same laboratory conditions $\left(27 \pm 1^{\circ} \mathrm{C}, 70 \% \mathrm{RH}\right.$, and 12:12 $\mathrm{h}$ photoperiod).

\section{Extraction of hemolymph and fat body}

The extraction of hemolymph and fat body was conducted on days $2,4,6,8$, and 10 after parasitism to investigate the possible changes that occur during the parasitoid's development. Sixteen caterpillars (eight parasitized and eight non-parasitized) were collected for evaluation at each time point. Two larvae were analyzed together resulting in four replicates per treatment. Hemolymph was collected with a micropipette; ten microliters of hemolymph were sampled from each caterpillar, mixed with 590 $\mu \mathrm{L}$ of anticoagulant buffer ( $98 \mathrm{mM} \mathrm{NaOH} ; 0.19 \mathrm{M}$ $\mathrm{NaCl} ; 1.7 \mathrm{mM}$ EDTA; and $41 \mathrm{mM}$ citric acid at $\mathrm{pH}$ $4.5)$ and centrifuged at $4900 \mathrm{rpm}$ for 2 minutes. The supernatant was collected and stored at $-20{ }^{\circ} \mathrm{C}$ for the biochemical analysis. These same caterpillars were dissected using an iced anticoagulant buffer (same as described above) under a stereoscope microscope. The fat body (parietal and perivisceral) was removed with a pair of tweezers (Tweezers Stainless steel plate 301 - Size 120 mm - Model 1231 SPLABOR), washed in anticoagulant buffer, and weighed in an analytical scale (BEL). Subsequently, 
$10 \mathrm{mg}$ of pooled fat bodies was transferred to microtubes containing $20 \mathrm{mg}$ of sodium sulfate and $200 \mu \mathrm{L}$ of methanol (75\%). These samples were macerated with a plastic pestle, which was washed with $600 \mu \mathrm{L}$ of 1:1 chloroform-methanol. Samples were centrifuged at $7400 \mathrm{rpm}$ for $3 \mathrm{~min}$ and the supernatant stored at $-20^{\circ} \mathrm{C}$ for later use.

Hemolymph and fat body concentrations of carbohydrate, lipid, and protein

The determination of nutrient levels in the hemolymph and fat body were conducted separately and in triplicate. Carbohydrates were quantified using the anthrone reagent (ROE, 1955) - 70 $\mu \mathrm{L}$ of centrifuged sample were mixed with 700 $\mu \mathrm{L}$ of reagent and heated at $100{ }^{\circ} \mathrm{C}$ for $15 \mathrm{~min}-$ absorbance was read at $620 \mathrm{~nm}$. Glucose was used as the standard for the calibration curve. Total lipid concentration was determined using the vanillin reagent (VAN HANDEL, 1985); hemolymph and fat body samples $(50 \mu \mathrm{L})$ were placed in a glass tube containing $200 \mu \mathrm{L}$ of chloroform-methanol (1:1) and brought to evaporation at $100{ }^{\circ} \mathrm{C}$. Immediately afterward, $30 \mu \mathrm{L}$ of sulfuric acid was added to these tubes, which were heated at $100{ }^{\circ} \mathrm{C}$ for $10 \mathrm{~min}$ to produce sulfonic acid derivatives. After cooling, vanillin was added $(1.72 \mathrm{~mL})$, and the tubes were vortexed to obtain a uniform color. Absorbance was read with the $525 \mathrm{~nm}$ filter using commercial soybean oil as the standard. Protein concentration was determined by the colorimetric assay using a commercial kit (Coomassie Plus Protein, Pierce Biotechnology) based on the Bradford method (BRADFORD, 1976); hemolymph and fat body samples $(10 \mu \mathrm{L})$ were mixed with $300 \mu \mathrm{L}$ of the Bradford reagent and read at $595 \mathrm{~nm}$ after 10 minutes. Bovine serum albumin was used as the standard curve. The data from the concentrations of all nutrients were compared by the t-test $(p<0.05)$ using the SAS software (SAS INSTITUTE, 2001).
Histological study

Paraffin sections of abdomens of parasitized and non-parasitized sixth instars caterpillars were prepared to determine the amount and location of the fat body remaining in the parasitized hosts at the end of parasitism. Parasitized and non-parasitized caterpillars were fixed in $10 \%$ buffered formalin for 24 hours on day 9. After the fixation period, they were cross-sectioned, dehydrated with graded ethanol and put in xylol for transparency and embedded in molten paraffin (56 to $60^{\circ} \mathrm{C}$ ). Paraffin blocks were serially sectioned at $7 \mu \mathrm{m}$ thickness using a microtome. The section obtained from the middle region of caterpillars were stained with PAS (periodic acid-Schiff) to detect the presence of glycogen in the fat body (JUNQUEIRA; JUNQUEIRA, 1983).

\section{Cytochemistry of hemocytes}

Hemolymph was collected as described previously and hemocytes were analyzed on day zero $(4 \mathrm{~h})$, three, and seven of parasitism. Three cytochemical staining techniques, Toluidine Blue (1\%), Mallory's Trichrome, and Sudan Black, were used to verify the presence of acid glycans, mucin, and lipids, respectively (JUNQUEIRA; JUNQUEIRA, 1983) in hemocytes. Images of slides were captured by a Sony ${ }^{\circledR}$ video camera coupled with an Olympus ${ }^{\circledR}$ BX50 microscope. The identification of hemocytes was conducted according to the criteria established by Silva et al. (2002) and Ribeiro and Brehelin (2006).

\section{Results}

Biochemical profile of the host's hemolymph

Cotesia flavipes parasitoid differentially induced changes in the levels of free protein and lipid in the hemolymph of D. Alavipennella (Figure 1). The effects of parasitism were not observed at the levels 
of carbohydrates between parasitized and nonparasitized caterpillars. Changes were observed on the tenth day of parasitism causing a reduction in protein concentration in parasitized caterpillars compared to the significant increase observed in the control group. Lipid levels were reduced within six days of parasitism; these levels approach those of non-parasitized caterpillars on days 8 and 10 of parasitism.

Figure 1. Levels of carbohydrate, protein, and lipid in the hemolymph of Diatraea flavipennella caterpillars $\left(6^{\text {th }}\right.$ instar), non-parasitized (control) and parasitized by Cotesia flavipes. ( ${ }^{*}$ Significant difference, $\mathrm{P}<0.05, \mathrm{n}=16$ ).
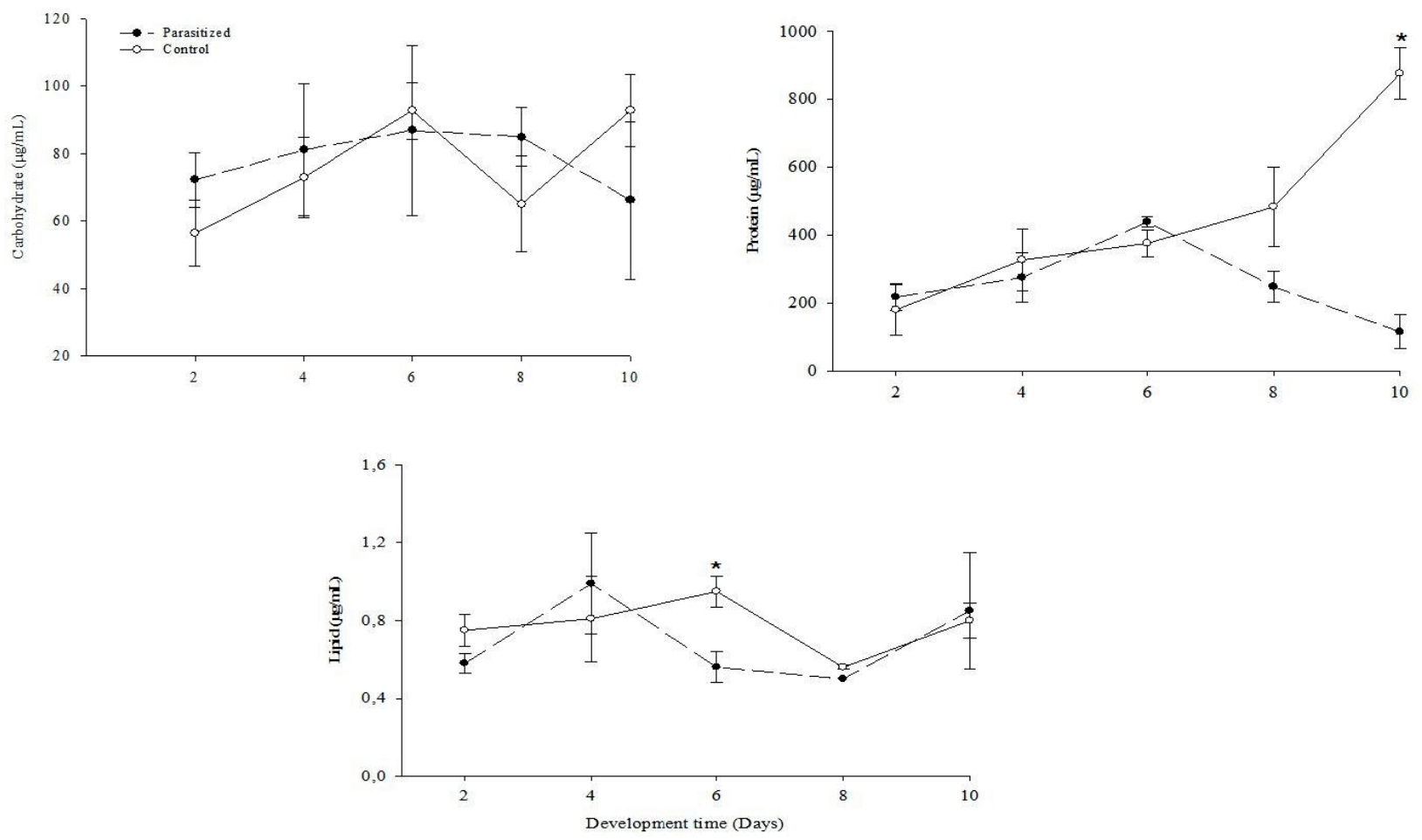

\section{Biochemical profile of the host's fat body}

The results of the biochemical analysis in the fat body (parietal and perivisceral) of parasitized and non-parasitized D. flavipennella showed that parasitism significantly altered the levels of carbohydrate and protein but not that of lipids (Figure 2). Initially, the carbohydrate concentration in parasitized caterpillars was higher than in the control group on the second day of parasitism; this concentration decreased significantly on the sixth and tenth day of parasitism. Protein levels were also higher in parasitized caterpillars than in the control group on the second day and decreased on the eighth day of parasitism. Protein levels increased in the control group during the evaluation period. At the moment of fat body extraction, during the evaluation of parasitism, a significant reduction in its volume was observed, which was confirmed by comparisons of weights and results in the histological analysis. We detected the reduction of $57.7 \%$ in its weight in parasitized caterpillars compared to this results in the control group on the ninth day after parasitism. 
Figure 2. Levels of carbohydrate, protein, and lipid in the fat body of Diatraea flavipennella caterpillars ( $6^{\text {th }}$ instar),

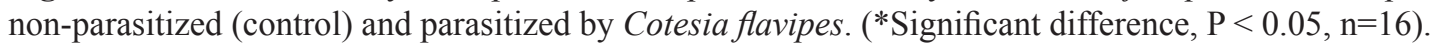
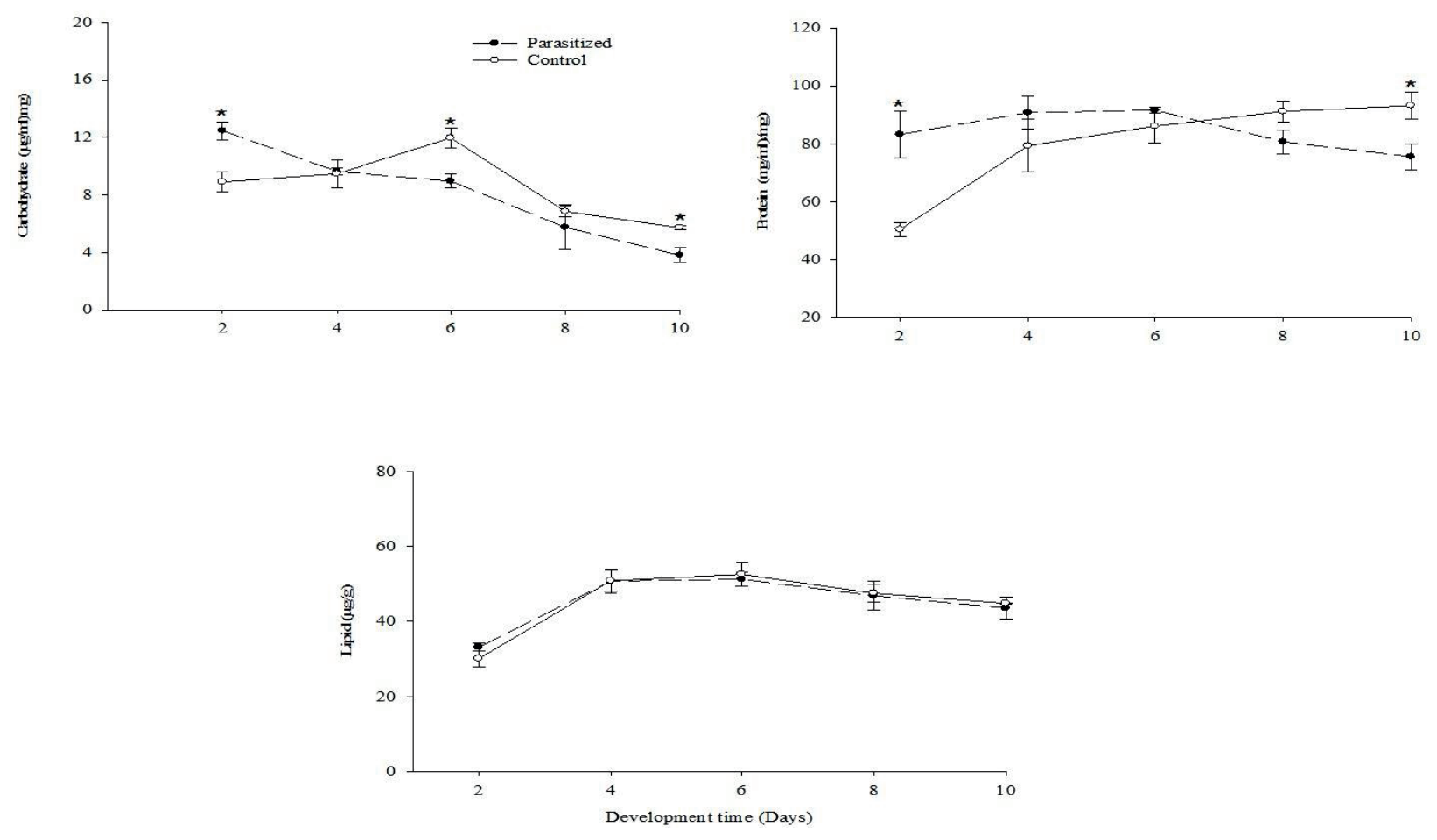

\section{Histological study}

The morphological observations showed that the fat body in D. flavipennella caterpillars is composed of two portions, parietal or peripheral (PA) and perivisceral (PE) (Figure 3A). The PA portion was present in small amounts and located immediately below the tegument, between it and the intersegment muscle. While the PE portion was present in larger amounts, it was observed surrounding the alimentary canal forming lamellar packages supported by tracheolar branches. Paraffin sections revealed that the parasitism caused a reduction in the fat body in parasitized caterpillars on day 9 and presented a significant effect on the PE portion of the fat body, which was almost completely consumed in contrast to the residual amount of the PA portion (Figure 3D). We also observed that the Periodic Acid-Schiff's reaction revealed positive staining areas (purple) in fat body tissue from nonparasitized caterpillars, making it possible to detect the strong presence of glycogen in the two portions of the fat body (Figures 3B and 3C) in contrast with that of parasitized caterpillars (Figures $3 \mathrm{E}$ and $3 \mathrm{~F}$ ). 
Figure 3. Cross section of Diatraea flavipennella caterpillars at the $6^{\text {th }}$ instar, non-parasitized $(\mathrm{A}, \mathrm{B}$, and $\mathrm{C})$ and parasitized (D, E, and F) by Cotesia flavipes. P.A.S. staining. -MG - midgut, PE - visceral fat body, H - hemocoel, PA - parietal fat body, MU - muscle, TE - Tegument, LP - parasitoid larva. (A and D Bars $=200 \mu \mathrm{m}, \mathrm{B}, \mathrm{C}, \mathrm{E}$, and F Bars $=50 \mu \mathrm{m})$.
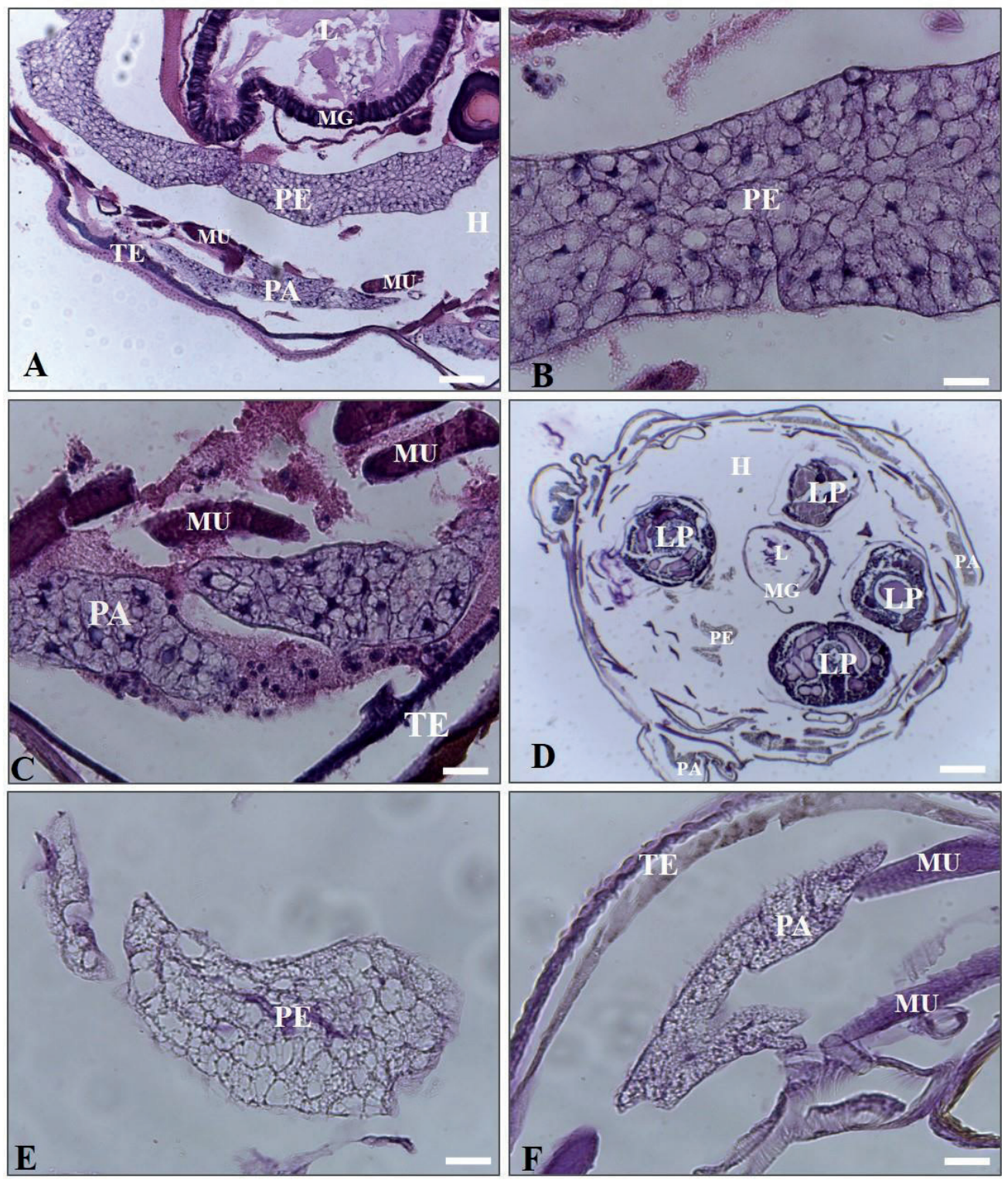

\section{Cytochemistry of hemocytes}

Histochemically, prohemocytes and oenocytoids reacted positively to Toluidine Blue (1\%) in nonparasitized caterpillars (Figures 4A and 4C). However, a weak response in these cells was observed at seven days of parasitism (Figures 4B and 4D). The Mallory Trichrome reaction revealed positive staining in plasmatocytes and granulocytes from the hemolymph of non-parasitized caterpillars (Figures 4E and 4G); on day 0 of parasitism, plasmatocytes reacted poorly to this staining (Figure 4F), and granulocytes reacted weakly throughout the evaluation period (Figure $4 \mathrm{H}$ and Table 1). Sudan Black positive reactions were visualized in granulocytes, prohemocytes, and adipohemocytes in non-parasitized caterpillars (Figures 5A, 5C, 
and 5E). In parasitized caterpillars, a weak reaction was observed in granulocytes on the third day of parasitism, in prohemocytes on the seventh day (Figures 5B and 5D), and throughout the evaluation period in adipohemocytes (Figure 5F and Table 1). Table 1 summarizes the staining results in the evaluated cells from the hemolymph of $D$. flavipennella.

Figure 4. Hemocytes obtained from the hemolymph of Diatraea flavipennella, parasitized (B, D, F, and H) and nonparasitized (A, C, E, and G) by Cotesia flavipes at different time points. A and B) Prohemocytes (day 7); C and D) Oenocytoids (day 7): Toluidine Blue (1\%) staining. E and F) Plasmatocytes (0 days); G and H) Granulocytes (day 3): Mallory Trichrome Staining. Bars $=10 \mu \mathrm{m}$.

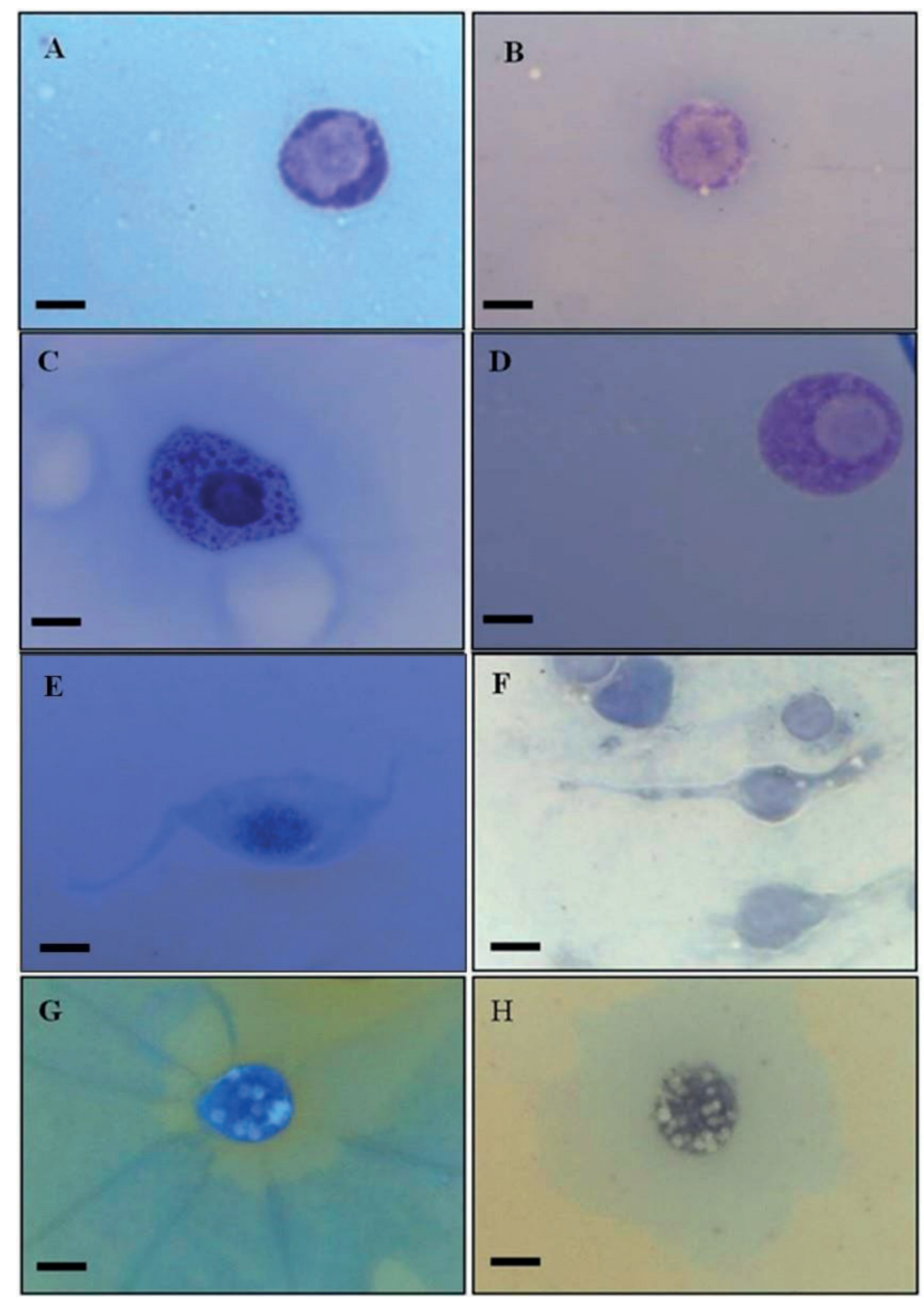


Figure 5. Hemocytes obtained from the hemolymph of Diatrea flavipennella, parasitized (B, D, F) and non-parasitized (A, C, E) by Cotesia flavipes at different time points. A and B) Granulocytes (day 3). C and D) Prohemocytes (day 7). E and F) Adipohemocytes (day 7). Sudan Black Staining, Bars $=10 \mu \mathrm{m}$.

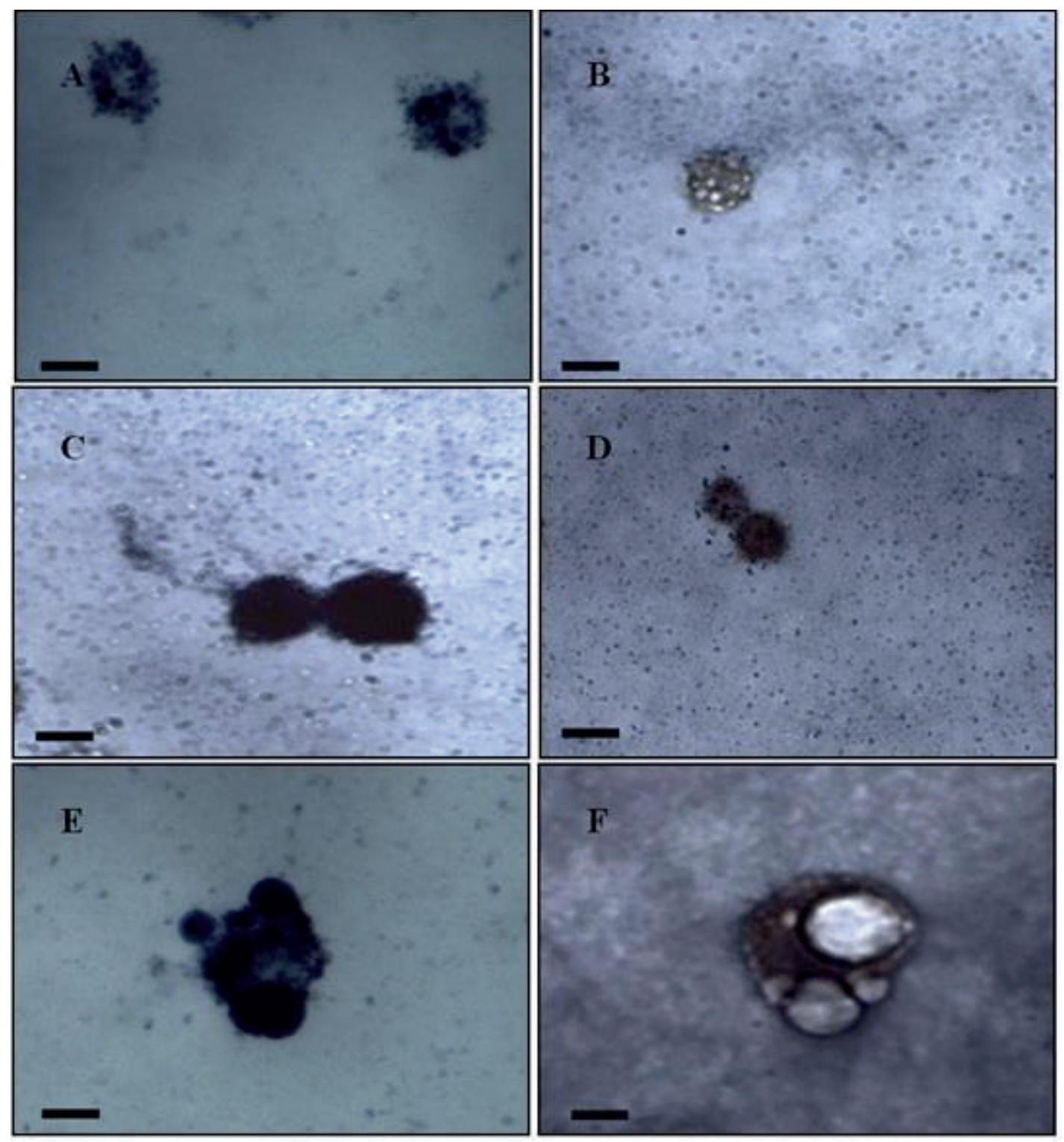




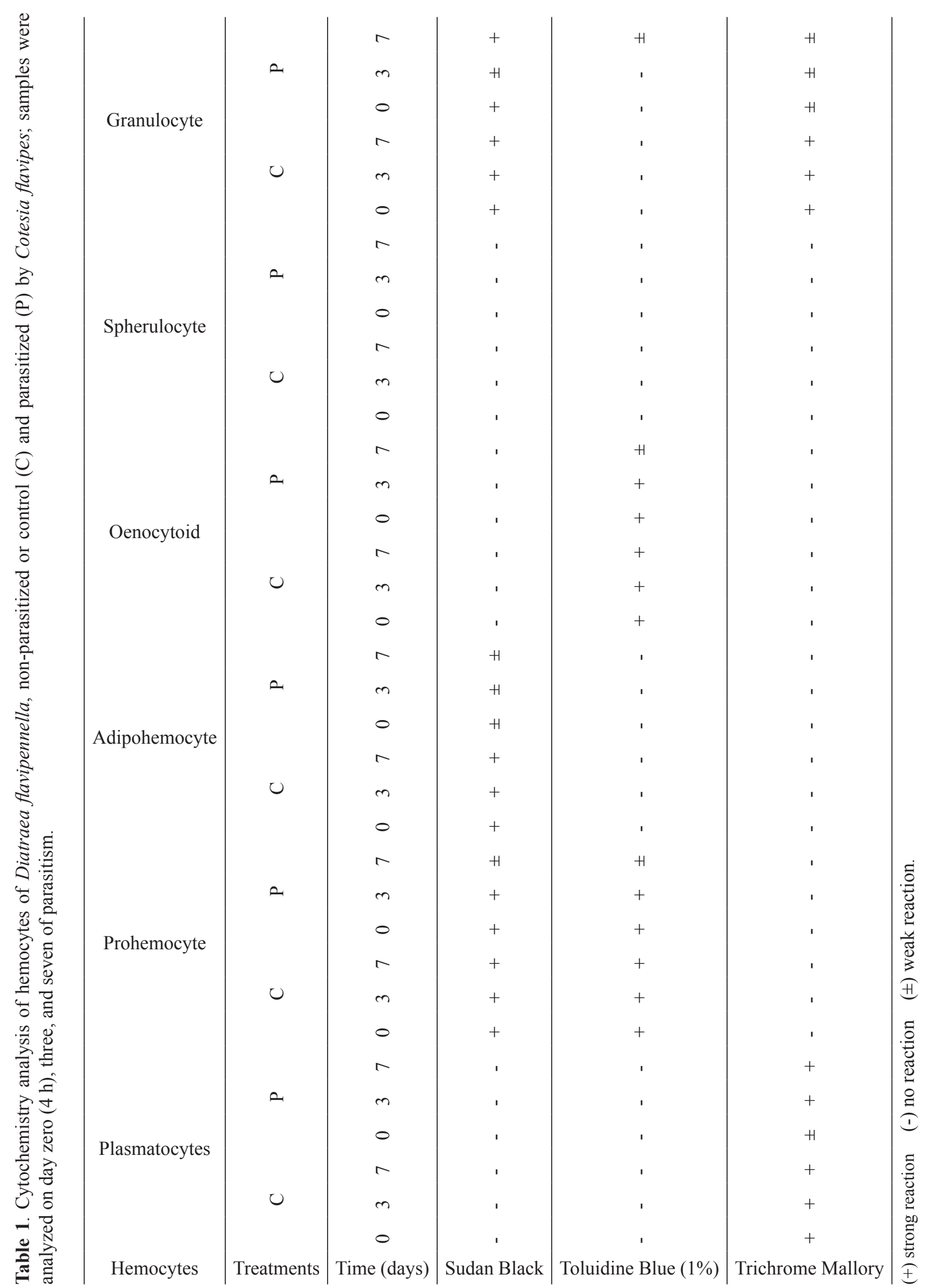




\section{Discussion}

A reduction in free nutrient levels in the hemolymph and fat body of $D$. flavipennela occurred from the sixth day of parasitism by $C$. flavipes when most of the parasitoid larvae were in the second instar. This fact might be related to the parasitoid developmental stage because parasitoid larvae remain in the first instar in the absence of an adequate host's nutritional status (SATO et al., 1986; NAKAMATSU et al., 2001). The observed hemolymph changes in the levels of proteins and lipids are explained by the fact that these macronutrients are essential element builders during morphogenesis, and therefore, are in high demand by immature parasitoid and host tissues, both in the development process (CHAPMAN, 2013). Thus, a constant competition for resources circulating in the hemolymph occurs between them (VINSON et al., 2001). The drastic reduction in the amount of protein in the hemolymph, at the end of parasitism, suggests that the parasitoid larvae consume protein from the host's hemolymph before emergence (NAKAMATSU; TANAKA, 2004).

Conversely, the increased levels of protein in the control group result from specific storage proteins that are synthesized by the fat body during the last larval instar and accumulated in the hemolymph to be used during metamorphosis (KANOST et al., 1990; HAUNERLAND, 1996; GULLAN; CRANSTRON, 2007).

Regarding lipids, they are sources of fat acids that serve as precursors for the synthesis of eicosanoids and pheromones required in substantial quantities for the synthesis of phospholipids (LOCKEY, 1988; STANLEY, 2006). Lipids may also be mobilized in the immune response process in the form of lipoproteins and used as energy source and/or membrane synthesis at infection sites or in hemocytes (MULLEN; GOLDSWORTHY, 2003; WHITTEN et al., 2004; RAHMAN et al., 2006; ARRESE; SOULAGES 2010). Thus, the effect on lipid mobilization from parasitism in $D$. flavipennella seems not to be only restricted to the hemolymph as reported in Diatraea saccharalis (Fabricius) parasitized by C. flavipes (SALVADOR; CÔNSOLI, 2008). Some hemocytes (granulocytes and prohemocytes) react weakly to Sudan Black staining, especially adipohemocytes evaluated in three periods because these cells are related to energy reserves (HILLYER; CHRISTENSEN, 2002).

The fat body is mainly linked to the function of nutrient storage; its reserves can be mobilized in response to other tissues' demands (ARRESE; SOULAGES, 2010). Therefore, changes in protein levels should be associated with the high demand of this nutrient in the hemolymph, which can probably be provided by the fat body. Moreover, the accumulation of storage proteins in the fat body is generally inhibited in parasitized caterpillars (BECKAGE; KANOST, 1993; SHELBY; WEBB, 1997; ZHANG et al., 1997). Similarly, one can infer that the demand for hemolymph carbohydrates for metabolic activities in the caterpillar and immature parasitoid are being met with the release of this nutrient by the fat body and hemocytes, prohemocytes, and oenocytoids, which showed a reduction in acidic polysaccharides levels on the seventh day of parasitism. The mobilization of carbohydrates to supply the needs of other tissues is mainly in the form of trehalose, which is a circulating sugar in the hemolymph (THOMPSON, 2003). Studies also describe a correlation between blood glucose levels and the main glycolysis regulator, showing that hemolymph glucose is an indicator of the condition of carbohydrate metabolism in the fat body, controlling its metabolism (ARRESE; SOULAGES, 2010).

The histochemical analysis also showed a reduction of mucins in hemocytes, mainly in granulocytes in parasitized larvae, suggesting an interference with the defense mechanism; mucins are known polymeric glycoproteins whose main function is to protect (DEPLANCKE; GASKINS, 2001; MYERS et al., 2008). In Drosophila 
melanogaster (Diptera: Drosophilidae), mucin is released from hemocytes, becomes part of the clot, and participates in the entrapment of bacteria (KORAYEM et al., 2004). Besides that, granulocytes are the first cells to recognize a foreign body in the process of encapsulation, fixing on it, and releasing their contents to an adhesive matrix on the target's surface, which induces the deposition of multiple layers of plasmatocytes (BECKAGE, 2006).

The significant reduction in the size of the perivisceral fat body observed in this study has been reported in other Lepidoptera larvae parasitized by Cotesia ssp (NAKAMATSU; TANAKA, 2004). According to the authors, when the host had enough of other nutrient resources (perivisceral fat body), the parietal fat body was not consumed. Even if the perivisceral fat body is damaged during the last larval stage, the damage to the host larvae may not be too great because the perivisceral fat body is a storage organ for pupation (WANG; HAUNERLAND, 1991). It is believed that the direct uptake of lipids from the host's tissue is more advantageous for the endoparasitoid larvae because it avoids metabolic costs associated with lipogenesis (GARRETT; GRISHAM, 1999). This absorption occurs through teratocyte cells that adhere to the fat body by releasing enzymes, such as collagenases, that dissociate cells from the fat body and release their contents to the parasitoid larvae (QIN et al., 2000; NAKAMATSU et al., 2002; FALABELLA et al., 2009). Several other proteins have been identified, including carboxylesterases specific to teratocytes that are involved in the hydrolysis of host lipids (GOPALAPILLAI et al., 2005). We evidenced teratocytes in caterpillars of D. flavipennella parasisted by C. flavipes (PASSOS et al., 2014)

The presence of parasitoids causes differential changes in the biochemical profile of the hemolymph and fat body in the $C$. flavipes-D. Alavipennella interaction. Furthermore, this interaction alters the cytochemistry of hemocytes and causes reduction in the reserve tissue, resulting in successful parasitism. Therefore, the results of this study contribute to consolidate biological control programs targeting this pest in sugarcane crops.

\section{Acknowledgments}

We are thankful to FACEPE for the financial support by granting a scholarship to the first author; the authors are grateful to Dra. Daniela de Oliveira Pinheiro (UEL) for the review of this study.

\section{References}

ARAÚJO, J. R.; BOTELHO, P. S. M.; ARAÚJO, S. M. S. S.; ALMEIDA, L. C.; DEGASPARI. N. Nova dieta artificial para criação da Diatraea saccharalis (Fabr.). Saccharum. Revista de Tecnologia Indústria Açúcar e Álcool, São Paulo, v. 36, n. 2, p. 45-48, 1985.

ARRESE, E. L.; SOULAGES, J. L. Insect fat body: energy, metabolism, and regulation. Annual Review of Entomology, Stanford, v. 55, p. 207-225, 2010.

BAE, S.; KIM, Y. Host physiological changes due to parasitism of a braconid wasp, Cotesia plutellae, on diamondback moth, Plutella xylostella. Comparative Biochemistry and Physiology Part B, Oxford, v. 38, n. 1, p. 39-44, 2004.

BECKAGE, N. E. Insect immunology. In: SCHOWALTER, T. D. Insect ecology: an ecosystem approach. San Diego: Academic Press, 2006. p. 243-270.

BECKAGE, N. E.; GELMAN, D. B. Wasp parasitoid disruption of host development: implications for new biologically based strategies for insect control. Annual Review of Entomology, Stanford, v. 49, p. 299-330, 2004.

BECKAGE, N. E.; KANOST, M. R. Effects of parasitism by the braconid wasp Cotesia congregata on host hemolymph proteins of the tobacco hornworm, Manduca sexta. Insect Biochemistry and Molecular Biology, Oxford, v. 23, n. 5, p. 643-653, 1993.

BRADFORD, M. M. A rapid and sensitive method for the quantitation of microgram quantities of protein utilizing the principle of protein-dye binding. Analytical Biochemistry, Orlando, v. 72, n. 1-2, p. 248-254, 1976.

CAMPOS-FARINHA, A. E. C.; CHAUD-NETTO, J.; GOBBI, N. Biologia reprodutiva de Cotesia flavipes (Cameron) (Hymenoptera: Braconidae). IV. Discriminação entre lagartas parasitadas e não parasitadas 
de Diatraea saccharalis Fabricius (Lepidoptera: Pyralidae), tempo de desenvolvimento e razão sexual dos parasitoides. Arquivos do Instituto Biológico, São Paulo, v. 67 , n. 2, p. 229-234, 2000.

CHAPMAN, R. F. The insects: structure and function. $4^{\text {ht }}$ ed. Cambridge: Cambridge, University Press, 2013. $770 \mathrm{p}$.

DEPLANCKE, B.; GASKINS, H. R. Microbial modulation of innate defense: goblet cells and the intestinal mucus layer. American Journal of Clinical Nutrition, Rockville, v. 73, n. 6, p. 1131-1114, 2001.

EDWARDS, J. P.; WEAVER, R. J.; MARRIS, G. C. Endocrine changes in lepidopteran larvae: Potencial challenges to parasitoid development and survival. In: EDWARDS, J. P.; WEAVER, R. J. (Ed.). Endocrine interactions of insect parasites and pathogens. Oxford: BIOS Scientific Publishers, 2001. p. 1-32.

ESPAGNE, E.; DUPUY, C.; HUGUET, E.; CATTOLICO, L.; PROVOST, B.; MARTINS, N.; POIRIE, M.; PERIQUET, G.; DREZEN, J. M. Genome sequence of a polydnavirus: Insights into symbiotic virus evolution. Science, Washington, v. 306, n. 5694, p. 286-289, 2004.

FALABELLA, P.; RIVIELLO, P.; DE STRADIS, M. L.; VARRICCHIO, P.; GRIMALDI, A.; EGUILEOR, M.; GRAZIANI, F; GIGLIOTTI, S.; PENNACCHIO, F. Aphidius ervi teratocytes release in extracellular enolase. Insect Biochemistry and Molecular Biology, Oxford, v. 39, n. 11, p. 801-813, 2009.

FREITAS, M. R. T.; FONSECA, A. P. P.; SILVA, E. L.; MENDONÇA, A. L.; SILVA, C. E.; MENDONÇA, A. L.; NASCIMENTO, R. R.; SANT'ANA, A. E. G. The predominance of Diatraea flavipennella (Lepidoptera: Crambidae) in sugar cane fields in the state of Alagoas, Brazil. Florida Entomologist, Lutz, v. 89, n. 4, p. 539540, 2006.

GARRETT, R. H.; GRISHAM, C. M. Biochemistry. Orlando: Saunders College Publishing, 1999. 1154 p.

GOPALAPILLAI, R.; KADONO-OKUDA, K.; OKUDA, T. Molecular cloning and analysis of a novel teratocyte-specific carboxylesterase from the parasitic wasp Dinocampus coccinellae. Insect Biochemistry and Molecular Biology, Oxford, v. 35, n. 10, p. 1171-1180, 2005.

GULlAN, P. J.; CRANSTON, P. S. Os insetos: um resumo de entomologia. São Paulo: Roca, 2007. 440 p.

HAUNERLAND, N. H. Insect storage proteins: gene families and receptors. Insect Biochemistry and Molecular Biology, Oxford, v. 26, n. 8-9, p. 755-765, 1996.
HENSLEY, S. D.; HAMMOND JÚNIOR, A. M. Laboratory technique for rearing the sugarcane borer on an artificial diet. Journal of Economic Entomology, Lanham, v. 61, n. 6, p. 1742-1743, 1968.

HILLYER, J. F.; CHRISTENSEN, B. M. Characterization of hemocytes from the yellow fever mosquito, Aedes aegypti. Histochemistry and Cell Biology, Berlin, v. 117, n. 5, p. 431-440, 2002.

JERVIS, M. A.; ELLERS, J.; HARVEY, J. A. Resource acquisition, allocation, and utilization in parasitoid reproductive strategies. Annual Review of Entomology, Stanford, v. 52, p. 361-385, 2008.

JUNQUEIRA, L. C. U.; JUNQUEIRA, L. M. M. S. Técnicas básicas de citologia e histologia. São Paulo: Guanabara Koogan, 1983. 123 p.

KAESLIN, M.; PFISTER-WILHELM, R.; MOLINA, D.; LANZREIN, B. Changes in the haemolymph proteome of Spodoptera littoralis induced by the parasitoid Chelonus inanitus or its polydnavirus and physiological implications. Journal of Insect Physiology, Oxford, v. 51, n. 9, p. 975-988, 2005.

KANOST, M. R.; KAWOOYA, J. K.; LAW, J. H.; RYAN, R. O.; HEUSDEN, M. C. V.; ZIEGLER, R. Insect haemolymph proteins. Advances in Insect Physiology, San Diego, v. 22, p. 299-396, 1990.

KORAYEM, A. M.; FABBRI, M.; TAKAHASHI, K.; SCHERFER, C.; LINDGREN, M.; SCHMIDT, O.; UEDA, R.; DUSHAY, M. S.; THEOPOLD, U. A Drosophila salivary gland mucin is also expressed in immune tissues: evidence for a function in coagulation and the entrapment of bacteria. Insect Biochemistry and Molecular Biology, Oxford, v. 34, n. 12, p. 1297-1304, 2004.

KROEMER, J. A.; WEBB, B. A. Polydnavirus genes and genomes:emerging gene families and new insights into polydnavirus replication. Annual Review of Entomology, Stanford, v. 49, p. 431-456, 2004.

LANZREIN, B.; PFISTER-WILHELM, R.; VON NIEDERHAÜSERN, F. Effects of an egg-larval parasitoid and its polydnavirus on development and the endocrine system of the host. In: EDWARDS, J. P.; WEAVER, R. (Ed.). Endocrine interactions of insect parasites and pathogens. Oxford: BIOS Scientific Publishers, 2001. p. 95-109.

LEE, S.; BASIO, N. A.; KIM, D. S.; KIM, Y. Proteomic analysis of parasitization by Cotesia plutellae against Diamondback Moth, Plutella xylostella. Journal of AsiaPacific Entomology, Suwon, v. 8, n. 1, p. 53-60, 2005. 
LOCKEY, K. H. Lipids of the insect cuticle-origin, composition and function. Comparative Biochemistry and Physiology Part B, Oxford, v. 89, n. 4, p. 595-645, 1988.

MENDONÇA, A. F. Guia das principais pragas da canade-açúcar na América Latina e Caribe. In: MENDONÇA, A. F. (Ed.). Pragas da cana-de-açúcar. Maceió: Insetos \& Cia, 1996. p. 3-48.

MENDONÇA, A. F.; RISCO, S. H.; COSTA, J. M. B. Introduction and rearing of Apanteles flavipes Cameron (Hymenoptera: Braconidae) in Brazil. International Society of Sugar Cane Technologists- ISSCT, São Paulo, v. 1, p. 703-710, 1977.

MULLEN, L.; GOLDSWORTHY, G. Changes in lipophorins are related to the activation of phenoloxidase in the haemolymph of Locusta migratoria in response to injection of immunogens. Insect Biochemistry and Molecular Biology, Oxford, v. 33, n. 7, p. 661-670, 2003.

MYERS, B. M.; FREDENBURGH, J. L.; GRIZZLE, W. E. Carbohydrates. In: BANCROFT, J. D.; GAMBLE, M. (Ed.). Theory and practice of histological techniques. Philadelphia: Elselvier, 2008. p. 161-186.

NAKAMATSU, Y.; GYOTOKU, Y.; TANAKA T. The endoparasitoide Cotesia kariyai $(\mathrm{Ck})$ regulates the growth and metabolic efficiency of Pseudaletia separata larvae by venom and Ck polydnavirus. Journal of Insect Physiology, Oxford, v. 47, n. 6, p. 573-584, 2001.

NAKAMATSU, Y.; FUJII, S.; TANAKA, T. Larvae of an endoparasitoid, Cotesia kariyai (Hymenoptera: Braconidae), feed on the host fat body directly in the second stadium with help of teratocytes. Journal of Insect Physiology, Oxford, v. 48, n. 11, p. 1041-1052, 2002.

NAKAMATSU, Y.; TANAKA, T. Correlation between concentration of hemolymph nutrients and amount of fat body consumed in lightly and heavily parasitized hosts (Pseudaletia separata). Journal of Insect Physiology, Oxford, v. 50, n. 2-3, p. 135-141, 2004.

PASSOS, E. M.; WANDERLEY-TEIXEIRA, V.; MARQUES, E. J.; TEIXEIRA, A. A. C.; BRAYNER, F. A. Cotesia flavipes (CAM) (Hymenoptera: Braconidae) supresses immune respnses in Diatraea flavipennella (BOX) (Lepidoptera: Crambidae). Anais da Academia Brasileira de Ciências, Rio de Janeiro, v. 86, n. 4, p. 2013-2024, 2014.

PECH, L. L.; STRAND, M. R. Granular cells are required for encapsulation of foreign targets by insect haemocytes. Journal of Cell Science, London, v. 109, n. 8, p. 2053-2060, 1996.
PINHEIRO, D. O.; ROSSI, G. D.; CÔNSOLI, F. L. External morphology of Cotesia flavipes (Hymenoptera: Braconidae) during larval development. Revista Brasileira de Zoologia, São Paulo, v. 27, n. 6, p. 986992, 2010.

QIN, Q. L.; GONG, H.; DING, T. Two collagenases are secreted by teratocytes from Microplitis mediator (Hymenoptera: Braconidae) cultured in vitro. Journal of Invertebrate Pathology, San Diego, v. 76, n. 1, p. 79-80, 2000.

RAHMAN, M. M.; MA, G.; ROBERTS, H. L. S.; SCHMIDT, O. Cell-free immune reactions in insects. Journal of Insect Physiology, Oxford, v. 52, n. 7, p. 754762, 2006.

RIBEIRO, C.; BREHELIN, M. Insect haemocytes: what type of cell is that? Journal of Insect Physiology, Oxford, v. 52, n. 5, p. 417-429, 2006.

ROE, J. H. The determination of sugar in blood fluid and spinal fluid with anthrone reagent. Journal Biological Chemistry, Baltimore, v. 212, n. 1, p. 335-343, 1955.

SALVADOR, G.; CÔNSOLI, F. L. Changes in the hemolymph and fat body metabolites of Diatraea saccharalis (Fabricius) (Lepidoptera: Crambidae) parasitized by Cotesia flavipes (Cameron) (Hymenoptera: Braconidae). Biological Control, Orlando, v. 45, n. 1, p. 103-110, 2008.

SATISTICAL ANALYSES SYSTEM - SAS. SAS/STAT. User's guide: statistics. version 8.02. Cary: Editora, 2001. v. 2.

SATO, Y.; TAGAWA, J.; HIDAKA, T. Effects of the gregarious parasitoids Apanteles rufricus and A. Kariyai on host growth and development. Journal of Insect Physiology, Oxford, v. 32, n. 4, p. 281-286, 1986.

SHELBY, K. S.; WEBB, B. A. Polydnavirus infection inhibits translation of specific growth-associated host proteins. Insect Biochemistry and Molecular Biology, Oxford, v. 27, n. 3, p. 263-270, 1997.

SILVA, J. E. B.; BOLELI, I. C.; SIMÕES, Z. L. P. Hemocyte types and total and differential counts in unparasitized and parasitized Anastrepha obliqua (Diptera, Tephritidae) larvae. Brazilian Journal of Biology, São Paulo, v. 62, n. 4, p. 689-699, 2002.

STANLEY, D. Prostaglandins and other eicosanoids in insects: biological significance. Annual Review of Entomology, Stanford, v. 51, p. 25-44, 2006.

THOMPSON, S. N. Trehalose: the insect blood sugar. Advances in Insect Physiology, San Diego, v. 31, p. 205285, 2003. 
VAN HANDEL, E. Rapid determination of total lipids in mosquitoes. Journal of the American Mosquito Control Association, Fresno, v. 1, n. 3, p. 302-304, 1985.

VINSON, S. B.; PENNACCHIO, F.; CÔNSOLI, F. L. The parasitoid-host endocrine interaction from a nutritional perspective. In: EDWARDS, J. P.; WEAVER, R. J. (Ed.). Endocrine interactions of insect parasites and pathogens. Oxford: BIOS Scientific Publishers, 2001. p. 187-206.

VISSER, B.; LANN, C. L.; BLANKEN, F. J.; HARVEY, J. A.; ALPHEN, J. J. M. V.; ELLERS, J. Loss of lipid synthesis as an evolutionary consequence of a parasitic lifestyle. Proceedings of the National Academy of Sciences, Washington, v. 107, n. 19, p. 8677-8682, 2010.

WANG, Z.; HAUNERLAND, N. H. Ultrastructural study of storage protein granules in fat body of the corn earworm, Heliothis zea. Journal of Insect Physiology, Oxford, v. 37, n. 5, p. 353-364, 1991.
WHITFIELD, J. B. Phylogeny and evolution of hostparasitid interactions in Hymenoptera. Annual Review of Entomology, Stanford, v. 43, p. 129-151, 1998.

WhitTEN, M. M. A.; TEW, I. F.; LEE, B. L.; RATCLIFFE, N. A. A novel role for an insect apolipoprotein (apolipophorin III) in \{beta\}-1,3-glucan pattern recognition and cellular encapsulation reactions. Journal of Immunology, Baltimore, v. 172, n. 4, p. $2177-$ 2185, 2004.

ZHANG, Z.; DAHLMAN, D. L; JÄRLFORS, U. E. Effect of Micropplitis croceipes teratocytes on host hemolymph protein content and fat body proliferation. Journal of Insect Physiology, Oxford, v. 43, n. 6, p. $577-$ $585,1997$. 
